DOI: 10.17707/AgricultForest.62.2.13

\author{
Željko SAVIĆ, Ognjen MAĆEJ, \\ Nenad DRAS̆KOVIĆ, Božidar MILOŠEVIĆl
}

\title{
INFLUENCE OF MILK ON THE CONTENT AND TOTAL PROTEIN CHANGES DURING RIPENING WHITE CHEESE IN INDUSTRIAL PRODUCTION
}

\begin{abstract}
SUMMARY
Sjenica cheese is one of the most famous of the group of white cheese in brine of the Republic of Serbia. Center of the production are mountain plateau surrounding the city Sjenica. It is produced by indigenous technology on individual farms, as well as in industrial conditions of micro dairies. The raw material for the production is fresh whole fat cow and sheep milk, which is made without the application of heat treatment. Because proteins are the most important parameter of chemical composition and milk quality, which affects the course of making cheese, and the quality and overall value of the cheese depends on them, it is necessary to establish their content and the changes during cheese ripening. Research results have shown that the total protein content of 1-day maturity in cow milk cheese was $14.80 \%$, and in sheep milk cheese $17.67 \%$. The differences between two kinds of cheese were statistically highly significant. The total protein content in both kinds of cheese during the first 30 days of ripening uniformly increased and it reached the maximum. After this period the total protein content was found in cow milk cheese $17: 54 \%$ and $19.07 \%$ in sheep milk cheese. These differences were statistically significant. In the last period of 30-45 days of maturity we had in both kinds of cheese a slight reduction in total protein levels. At the end of the ripening period of 45 days, total protein ranged in cow milk cheese $17,41 \%$ and $18.75 \%$ in sheep milk cheese. These differences were statistically significant.
\end{abstract}

Keywords: Sjenica cheese, total protein, ripening

\section{INTRODUCTION}

Sjenica cheese is one of the most famous of the group of white cheese in brine of the Republic of Serbia. It is produced by the indigenous technology on individual farms on mountains plateau that surround town of Sjenica, but recently more and more in industrial conditions of mini-dairies. The raw material for production is fresh whole fat cow milk and sheep milk, which process of making cheese starts immediately after milking, without the application of heat treatment.

\footnotetext{
1̌Željko SAVIĆ (corresponding author: zeljkosavic65@hotmail.rs), Nenad DRASKOVIC, University of Pristina, Fakulty of Agriculture, Kosovska Mitrovica-Lesak, SERBIA, Božidar MILOŠEVIĆ, University of Pristina, Fakulty of Agriculture, Kosovska Mitrovica-Lesak, SERBIA, Ognjen MAĆEJ, University of Belgrade, Fakulty of Agriculture, Belgrade-Zemun, SERBIA

Notes: The authors declare that they have no conflicts of interest. Authorship Form signed online.
} 
The quality and overall value of cheese, depends primarily on the quality and chemical composition of milk, where the highest importance has a dry matter content, fat and protein. Milk from certain types of dairy animals has a specific chemical composition, which is reflected significantly on manufacturing and the chemical composition of cheese.

Of all components of milk the greatest importance, in the production of the vast majority of cheese, belongs to casein. Casein is the most abundant protein in milk which makes $75-80 \%$ of total milk protein. Casein is a complex composition and belongs to the group of fosfogliko proteins (Maćej et al., 2007; Jolles, P. and Fiat, A.M. 1979). The technological process of cheese production is based on the specific properties of the casein in the framework of which the most important are the ability of coagulation and gel-forming, ability of the formed gel towards sinerezisu and tendency to proteorizi under the influence of proteolytic enzymes present in cheese. The most important characteristics of casein secure transformation of milk from liquid aggregate state in firm state, concentration of a part of milk dry matter and the formation of the desired sensory properties of the cheese during its ripening.

When coagulation and formation of a gel, casein micelles appear as constitutive elements of the matrix protein, during syneresis due to the increase of acidity, there is a dissociation of colloidal calcium phosphate (CCP), an integral part of the casein micelles in which chunks are depleting the calcium content. Depending on the course of acidity, during the process of making cheese, the proper amount of demineralization casein will be realized, which will regulate mineral composition of cheese (Pudja, 2009).

Numerous factors influence on the primary and secondary phase of milk coagulation and rheological properties of curd, but the most important is the concentration of casein. Coagulation rate is directly proportional to the concentration of casein, and the resulting curd is firmer (Bringe, and Kinsella, 1986).

Mijočinović (2013), states that the firmness of the gel is directly correlated with the content of casein.

Smaller content of casein in milk contributes to formation of curd of less strength, so during its treatment loss of fat from whey is greater and there is a significant loss of protein in the form of cheese dust (Pudja, and Maćej, 1996,; Pudja et al., 1996).

Pudja (2009) points out that in defining the microstructure of cheese; cream cheese dough includes 3 phases, one of which is a protein phase. The protein matrix forms the basis of the structure of the cheese. Mineral complex of cheese is largely incorporated into it, and closely associated with it, so that they are the holders of not only the structure and elasticity of cheese but represent potential and basis for changes during cheese ripening.

The most significant changes during ripening occur in proteins, starting on milk from the time of adding rennet (Fenelon, and Guinee, 2000). 
In a series of changes that occur in cheese during ripening, changes on proteins and their products of formation are the most important, so in the literature the term cheese ripening in the strict sense implies changes of proteins. The scope and depth of proteolytic changes are closely related to the technology of making cheese, ripening conditions and the activity of microorganisms, and have a decisive influence on the formation of the sensory characteristics, consistency and rheological properties of cheese (Fox, 1989).

\section{MATERIAL AND METHODS}

The experiment was performed in June 2012. All types of cheese were produced in industrial conditions of "Pester" dairy in Sjenica. Basic principles of production, during the production process of cheese, were as follows:

-Milk: Full fat cow and sheep milk.

-Preparing and the process of making cheese: included the draining, filtering and reheating at coagulation temperature. The temperature during the process of making cheese was $32 \mathrm{oC}$, and the time was $50 \mathrm{~min}$.

-Treatment of curd: the curd was cut into cubes - size $5 \times 5 \mathrm{~cm}$, and then placed in a strainer. Dewatering was carried out on the table with the application of pressing, and it lasted two hours. After filtering and separation of whey, the clod was formed.

Cheese cutting and salting: clod was cut into slices of $15 \times 15 \times 5 \mathrm{~cm}$ and $10 \mathrm{X} 10 \mathrm{X} 3 \mathrm{~cm}$. The cheese was salted successively with dry, sea salt, during stacking in the packaging.

-Ripening: It was occured in salty whey, and optimal ripening period was 40 days.Research goal: to determine the levels of total protein after making cheese, and then to monitor the dynamics during maturation after 15, 30 and 45 days of ripening.

-Analysis: The analyzes were carried out at the Veterinary-Specialistics Institute of Kraljevo by following methods

-Determination of total nitrogen by Kjeldahl method, using kjeltek device (Carić et al.,2000)

The total protein content was calculated by multiplying the total nitrogen content with a factor of 6.38 (Standard IDF 20-1: 2002). Both kinds of cheese are made in 5 repetitions and the total sample number was 10 .

Determination of total nitrogen by Kjeldahl method

Apparatus and accessories:

Analytic scales; - Digestion hot plate where Kjeldahl's flask is placed; Distillation apparatus; -Erlenmajer, $500 \mathrm{ml}$; -Menzure, 25, 50, 100 and $150 \mathrm{ml}$; Bireta, $50 \mathrm{ml}$; Substances that facilitate boiling: pieces of porcelain or glass beads for digestion, freshly calcined pieces of pumice for distillation.

Reagents:

Catalyst: crystalline copper sulphate or a mixture of copper sulfate and potassium sulfate, in 1:15 relation;

$40 \%$ solution of sodium hydroxide; 
$0.1 \mathrm{~mol} / \mathrm{l}$ sodium hydroxide solution;

$0.05 \mathrm{~mol} / 1$ of sulfuric acid solution or $0.1 \mathrm{~mol} / 1$ solution of hydrochloric acid-

Indicator: $0.5 \%$ of metilred solution

Procedure:

In Kjeldahl flask's measure 1.5 to $2 \mathrm{~g}$ of the cheese, than add $25 \mathrm{ml}$ of concentrated $\mathrm{H} 2 \mathrm{SO} 4$, and about 0.5 of a catalyst. Burn it on the digestion hot plates, chill and then add up to $200 \mathrm{ml}$ of water stir and leave to chill again. Erlenmeyer flask to which was added $50 \mathrm{ml}$ of $0.1 \mathrm{~mol} / 1 \mathrm{HCl}$ solution or 0.05 mol / 1 H2SO4 solution, and four drops of indicator solution, place under the condenser so that the condenser tube was immersed in a solution of acid. Before the start of distillation, add about $80 \mathrm{ml}$ of $40 \% \mathrm{NaOH}$ solution.

The distillate titrated $0.1 \mathrm{~mol} / 1$ sodium hydroxide solution.

Total nitrogen (UN) in cheese is calculated by the following formula:

$\mathrm{UN}=(\%)$

Where is:

C-concentration of $\mathrm{HCl}(0.1 \mathrm{~mol} / \mathrm{l})$;

$\mathrm{V} 1-\mathrm{HCl}$ volume consumed for the binding of ammonia ( $\mathrm{ml})$;

-V2 Volume of $\mathrm{NaOH}$ consumed for the titration of the distillate $(\mathrm{ml})$;

m-Balanced sample mass of cheese $(\mathrm{g})$

-Statistical Analysis: The experiment was conducted with two types of milk by 5 repetitions. The analysis included:

-to define the significance of differences of arithmetic means and, also measures of variation

- standard deviation ( $\mathrm{Sd})$ and coefficient of variation $(\mathrm{Cv})$. -

To test differences of arithmetic means, we used Student's (t-test) (Stankovic et al., 1989).

\section{RESULTS AND DISCUSSION}

Production of white cheese in industrial conditions, unlike traditional production, provides a standard technology and consistent cheese quality. A similar statement gives (Jandric et al.,2015), which state that the opening of a mini-enterprises-small dairies in the area of Peshter, the economy of production and milk processing and product quality improve, as well as the incentive of milk producers and certain sale on the market.

When we talk about the content of protein and its changes, it should bear in mind the fact that the both kinds of cheese are made from milk, which process of making cheese is done without the application of heat treatment, but serum proteins leave the whey and do not participate in the formation of the curd. Additionally, when cheese is produced in this way, the base of protein matrix makes casein, which readily undergoes changes during the ripening. On the other hand, curd processing is simple and there is no application of high temperature, significantly affects the activity of rennet-chymosin and plasmin which in kinds 
of cheese produced in this way plays an important role in the process of ripening. The research results are presented in Table 1.

Table 1. Dynamics of total protein during cheese ripening $\%$.

\begin{tabular}{|c|c|c|c|c|c|}
\hline \multirow{2}{*}{$\begin{array}{c}\text { Cheese } \\
\text { type }\end{array}$} & \multirow{2}{*}{ Parametres } & \multicolumn{4}{|c|}{ Period of maturity(days) } \\
\cline { 2 - 6 } & & 1 & 15 & 30 & 45 \\
\hline \multirow{4}{*}{$\begin{array}{c}\text { Cow milk } \\
\text { cheese }\end{array}$} & $\min$ & 14.16 & 13.52 & 15.18 & 15.69 \\
\cline { 2 - 6 } & $\overline{\max }$ & 15.75 & 15.82 & 19.20 & 19.01 \\
\cline { 2 - 6 } & $\bar{x}=(\mathrm{n}=5)$ & 14.80 & 15.37 & 17.54 & 17.41 \\
\cline { 2 - 6 } & $\mathrm{Sd}$ & 0.08 & 0.17 & 0.23 & 0.16 \\
\hline \multirow{4}{*}{$\begin{array}{c}\text { Sheep milk } \\
\text { cheese }\end{array}$} & $\min$ & 3.44 & 7.31 & 8.52 & 6.07 \\
\cline { 2 - 6 } & $\max$ & 19.14 & 16.71 & 18.50 & 18.11 \\
\cline { 2 - 6 } & $\bar{x}=(\mathrm{n}=5)$ & 17.67 & 19.65 & 19.84 & 19.20 \\
\cline { 2 - 6 } & $\mathrm{Sd}$ & 0.14 & 0.15 & 0.07 & 0.06 \\
\cline { 2 - 6 } & $\mathrm{Cv} \%$ & 5.37 & 5.45 & 2.43 & 2.34 \\
\hline
\end{tabular}

\begin{tabular}{|c|c|l|}
\hline \multicolumn{3}{|c|}{ Significance of mean } \\
\hline \multicolumn{3}{|c|}{ t cal. $\bar{X}_{1}-\bar{X}_{2}$} \\
15 & 6.25 & $0.45^{* *}$ \\
30 & 1.58 & 0.16 \\
45 & 2.24 & $0.24^{*}$ \\
& 2.76 & $021^{*}$ \\
\hline
\end{tabular}

The theoretical value of ' $t$ ' schedules refer to the number of freedom deegrees (df) 12 and amounts: $p<0.05=2,179$; $p<0.01=3.05$.

Based on the results shown in the table one we had both in cow and sheep milk cheese, during the first 30 days of ripening, increase in total protein, when we recorded the maximum, which is due to an increase in dry matter content of cheese in the same period of ripening.

On the first day of ripening total protein content in cow milk cheese averaged $14.80 \%$ and $17.67 \%$ in sheep milk cheese. Treatment of the results showed that the differences between the both kinds of cheese were highly significant.

In the further course of maturation it is noticed further increase of the content of total protein in both kinds of cheese, as a result of the water content reduce, and this increase was $0,57 \%$ in cow milk cheese, and in sheep milk cheese $0.64 \%$. After 15 days of ripening content of total proteins in cow milk cheese was 15, 37\% and 18,31\% in sheep milk cheese. Analysis of the data showed that these differences were not statistically significant.

After a 30-day of maturity further increase of the content of total protein is noticed in both kinds of cheese. This increase in average was $2.17 \%$ in cow milk 
cheese and in sheep milk cheese $0.76 \%$. After this period of ripening total protein content of cow milk cheese was $17,54 \%$ and $19.07 \%$ in sheep milk cheese. These differences between the both kinds of cheese were statistically significant. At the end of the ripening period of the 45-day total protein content in cow and sheep milk cheese practically remained at the same level as after 30 days of ripening and it was $17,41 \%$ in cow milk cheese and $18.75 \%$ in sheep milk cheese. Treatment of the results showed that the differences between the cheeses were statistically significant.

Results of experiments confirmed the earlier thesis that there is a mutual dependence between the content of dry matter and total protein in white cheese. A slight decrease in the total protein content of the last 15 days of ripening is the result of crossings part of soluble protein from the cheese into the brine for ripenin.

During cheese ripening, milk proteins are the main substrate for enzymes. Enzyme activity, as well as flow, intensity and the extent of degradation of proteins depend on many factors, where the great importance has salt content in cheese whose effect is inhibitory, which is reflected in lower soluble protein content in cheese (Savic et al., 2015).

The results are consistent and do not differ significantly from the results of other authors for similar types of cheese and these groups: fat cheese Montenegro 17.47\% (Adžić et al., 1984); Pljevaljski cheese 19.73\% Polimsko- Vasojevićki 18.65\% Polimsko- Sjenički 17.15\% (Dozet et al., 1996); Domiati 16:42\% (Abdel Salam et al., 1993); White cheese-slice 12.15\% (Zivic, 1989); Homoljski 17:32\% (Jovanovic et al., 2004); Sjenički 14.85\%, Zlatarski 16.91\%,(Maćej et al., 2006\%); 13.79\% Sjenički cheese and Sjenica type cheese 15:39\% (Savić, 2011); Sjenica type cheese $11.07 \%$ (Popović-Vranješ et al., 2011).

\section{CONCLUSIONS}

Proteins are one of the most important parameters of the chemical composition of milk and cheese, which affects the speed of enzymatic and physical-chemical phase of milk coagulation, and thus the composition, strength and technological properties of the resulting curd.

Proteins are the basis of the structure of the cheese in which are incorporated other components of milk, especially milk fat and minerals, some of which depend on strength, consistency, rheological and other properties of cheese.

Cheese ripening includes changes in the protein, because the deepest changes occur on them, in other words, proteins serve as a substrate for the enzyme activity during ripening.

Of the many products of ripening, the most important are soluble nitrogen materials, occurred as the result of degradation of proteins, which contribute to the formation of the desired sensory characteristics of cheese.

A type of milk is a very important factor in the chemical composition of any kind of cheese. Sheep's milk, which content is richer with protein, actually 
casein, seriously affected on the total protein content in mature cheese. The content of total protein in mature sheep milk cheese amounted $18.75 \%$ in average, and in cow milk cheese it was 17:41\%. By data processing, these differences were statistically significant.

Due to its rich chemical composition, mainly to proteins, sheep's milk presents original and irreplaceable raw materials for the production of highprotein cheese, for its specific taste, and good organoleptic properties.

\section{REFERENCES}

Abd El Salam, M. H.; Alichanidis E.; Zerfiridis, GK. (1993): Domiati and Feta Type Cheese. P.F. Fox (Editor): Cheese; Chemistry, physics and microbiology, London.

Adžić, N.; Ljumović, M.; Tomović, M.; Dozet, N.; Stanišić, M.; Perović, M. (1984): The quality of milk for cheese production Njeguski. Mljekarstvo 34/3.

Bringe, N.A. and Kinsella, J. E. (1986): Influence of calcium chloride on Chymosininitiated coagulation of casein micelles. J. Dairy Res. 53 (3), 371-379.

Carić, M.; Milanović, S.; Vučelja, D. (2000): The Standard Methods of Analysis of Milk and Dairy Products, Faculty of Technology, Novi Sad

Dozet, N.; Adzić, N.; Stanisic, M.; ŽiviĆ, N. (1996): Indigenous Dairy Products, Agricultural Institute, Podgorica, SILMIR, Belgrade

Fenelon, MA and Guinee, TP. (2000): Flavor development in low-fat cheese. Cheese symposium. Ed.by Cogan, TM, McSweeney, P.L.H. and Guinee, TP, Moorepark, 31-42.

Fox, PF. (1989): Proteolysis during cheese manufacture and ripening. J. Dairy Sci. 72 (6), 1379 to 1400.

Jandrić,M.; Vasiljević, Z.; Kovačević, V.(2015): Financing the dairy sector in rural areas of the republic of serbia: pešter region example ,Agriculture \& Forestry, Vol. 61 Issue 1: 273-278, 2015, Podgorica.

Jolles, P. and Fiat, A-M. (1979): The carbohydrate portions of milk glycoproteins. J. Dairy Res. 46 (2), 187-191.

Jovanovic, S.; Maćej, O.; Barać, M. (2004): Changes during ripening of Svrljiški and Homoljski cheese, Biotechnology in animal husbandry, Vol. 20 (1-2), 109-117

Maćej, O.; Jovanovic, S.; Barać, M. (2007): Proteins of milk-Monograph, Faculty of Agriculture, University of Belgrade

Maćej, A.; Dozet, N.; Jovanovic, S. (2006): Characteristics of Indigenous Production of Sjenica, Homoljski, Zlatarskis and Svrljiski White Cheese, Monograph "Indigenous White Cheese in Brine" Editors Maćej, O. And Dozet, N. 33-65, Faculty of Agriculture, Beorad

Miočinović, J. (2013): Technology of milk, Practicum, Faculty of Agriculture, University of Belgrade

Popović-Vranješ, A.; Pejanović, R.; Ostojić, M.; Bauman, F.; Cvetanović, D.; GlavašTrbić, D.; Tomaš, M. (2011); Production of Sjenica chesse type in industrial conditions, Food industry- Milk and daidy products. 1 (47-51). Vol.22.

Pudja,P.; Maćej, O.; Dozet, N.; Jovanovic, S.; Mikuljanac, A. (1996): Influence of milk proteins on the rheological properties of cheese. Biotechnology in Animal Husbandry 12 (1-2), 37-44.

Pudja, P. (2009): Technology of milk and cheese, Faculty of Agriculture, Belgrade 
Pudja,P.; Maćej, O. (1996): Modern production of cheeses and development prospects. The monograph "Dairies." Reg. Pudja, P.D. Belgrade, 50-63.

Savić,Ž.; Maćej,O.; Milošević,B.; Radović,B. (2015): Significance and dyinamics of salt during storage and ripening of white cheese in industrial production. Agriculture \& Forestry, Vol.61, Issue 4: 271-276, 2015, Podgorica.

Savić. Ž. (2011): Changes of Nitrogen Compounds during Ripening of Sjenica Cheese and Cheese In Type of Sjenica, Doctoral dissertation, Faculty of Agriculture, University of Priština

Stankovć, J.; Ralević, N.; Ljubanović-Ralević, I. (1989): Statistics with Applications in Agriculture, Modern Administration, Belgrade

Živić, N. (1989): Energy value and quality of milk and dairy products from the area of Niš region, Doctoral dissertation, Faculty of Agriculture, Sarajevo 